\title{
Lack of evidence to support the association of a single IL28B genotype SNP rs 12979860 with the HTLV-1 clinical outcomes and proviral load
}

\author{
Sabri Saeed Sanabani ${ }^{1,2^{*}}$, Youko Nukui ${ }^{3}$, Juliana Pereira ${ }^{3}$, Antonio Charlys da Costa ${ }^{1}$, \\ Ana Carolina Soares de Oliveira ${ }^{1}$, Rodrigo Pessôa ${ }^{1}$, Fabio Eudes Leal ${ }^{4}$, Aluisio C Segurado ${ }^{5}$, \\ Esper Georges Kallas ${ }^{4}$ and Ester Cerdeira Sabino ${ }^{5}$
}

\begin{abstract}
Background: The Interleukin 28B (IL28B) rs12979860 polymorphisms was recently reported to be associated with the human T-cell leukemia virus type 1 (HTLV-1) proviral load (PVL) and the development of the HTLV-1-associated myelopathy/tropical spastic paraparesis (HAM/TSP).

Methods: In an attempt to examine this hypothesis, we assessed the association of the rs12979860 genotypes with HTLV-1 PVL levels and clinical status in 112 unrelated Brazilian subjects (81 HTLV-1 asymptomatic carriers, 24 individuals with HAM/TSP and 7 with Adult T cell Leukemia/Lymphoma (ATLL)).

Results: All 112 samples were successfully genotyped and their PvLs compared. Neither the homozygote $T$ nor the heterozygote CT mutations nor the combination genotypes (TT/CT) were associated with a greater PvL. We also observed no significant difference in allele distribution between asymptomatic carriers and patients with HTLV-1 associated HAM/TSP.
\end{abstract}

Conclusions: Our study failed to support the previously reported positive association between the IL28B rs12979860 polymorphisms and an increased risk of developing HAM/TSP in the Brazilian population.

Keywords: HTLV-1, ILB 28 polymorphisms, HAM/TSP, Proviral load

\section{Background}

Human T-lymphotropic virus type I (HTLV-I) is an oncogenic human retrovirus that was first isolated from a T-cell line, HUT102, that had been obtained from a patient with adult T-cell leukemia/lymphoma (ATLL) [1]. Globally, there are an estimated 10-20 million individuals that carry the HTLV-I [2]. The disease burden is unevenly distributed, with a higher incidence of the disease particularly in southwest Japan, the Caribbean islands, South America, and portions of Central Africa [3]. Infection with HTLV-I may result in a spectrum of clinical manifestations, ranging from asymptomatic infection to a number of human disorders, most notably a

\footnotetext{
*Correspondence: sabyem_63@yahoo.com

'Clinical Laboratory, Department of Pathology, LIM 03, Hospital das Clínicas (HC), School of Medicine, University of São Paulo, São Paulo, Brazil ${ }^{2}$ São Paulo Inistitute of Tropical Medicine, São Paulo, Brazil Full list of author information is available at the end of the article
}

malignant ATLL and a chronic progressive neuromyelopathy, termed HTLV-I-associated myelopathy/tropical spastic paraparesis (HAM/TSP) [4]. The majority of HTLV-I-infected individuals remain asymptomatic for life, while some individuals progress to a preleukemic phase that is characterized by small numbers of circulating leukemic cells in the peripheral blood, skin lesions, and a lack of involvement of other organ systems [5]. Only $2.5 \%$ to $5 \%$ of the virus carriers eventually develop ATLL after a long asymptomatic period [6,7]. The reason why some people develop disease, whereas others remain healthy, is likely dependent on both host-related and virus-related factors [8]. Available evidence from molecular studies indicate that the impairment of various cellular functions by viral genes (e.g., tax and $H B Z$ ), genetic and epigenetic changes including DNA methylation, and the host immune system may contribute to the leukemogenesis of ATLL [9-11].

\section{Ciomed Central}


Cytokines play an indispensable role in the defense against viral infection, both indirectly through determination of the predominant pattern of the host response and directly through significant inhibition of viral replication [12]. In attempts at explaining the heterogeneity of HTLV-I courses and outcomes, considerable attention in recent years has been paid to the single nucleotide polymorphisms (SNPs) in host genes that encode cytokine receptors and human leukocyte antigen (HLA) class I and II [13-19]. For example, multiple studies have suggested an association between polymorphisms at the IL- 6 and IL-10 promoters, at position -634 and -592 , respectively, and the pathogenesis of HAM/TSP $[18,19]$. In contrast, genetic variation at site -592 resulted in no association in other study analyzing the impact of these polymorphisms on the risk of HAM/TSP in Brazilian patients [20]. In another study, a $857 \mathrm{~T}$ polymorphism in tumor necrosis factor $\alpha$ (TNF- $\alpha$ ), which is a potent immuno-modulator and proinflammatory cytokine, has been shown to be associated with ATLL patients compared to healthy subjects, suggesting that the genetic alteration that increases the production of TNF- $\alpha$ is associated with a susceptibility to ATLL [13].

Recently, three independent genome-wide association studies identified several polymorphisms, such as rs8099917, rs12979860, and 12980275, in or near the IL28B gene in patients infected with hepatitis C virus genotype 1 who had previously been treated with a com bination of pegylated IFN- $\alpha$ and ribavirin [21-23]. The polymorphism rs12979860 (3 kb upstream of IL28B), identified by Ge et al., [21] was described as the SNP with the strongest association to sustained virological response, which is defined as the undetectability of HCV RNA 6 months after stopping therapy. This breakthrough association has now been found in various studies worldwide [24-27]. Interestingly, HTLV-1 infected individuals with the CT/TT allelic variants at the IL28B rs12979860 gene exhibited approximately a 3-fold increased risk of HAM/TSP and had nearly 10-fold higher median HTLV-1 proviral loads (PvLs) than CC carriers [28]. To investigate the consistency of this association, we chose to further scrutinize the role of the IL28B rs12979860 polymorphism in both asymptomatic HTLV1 carriers and in infected individuals that display clinical symptoms $(n=112)$, in correlation to PvL.

\section{Methods}

All patients were Brazilian and were recruited from the HTLV-1 outpatient clinic at the University of Sao Paulo, Brazil. We were unable to recruit more subjects, which would have enhanced the power of the study, and the total number of subjects was thus limited to 112 . Thus, our study has an $80 \%$ power to detect a minimum odds ratio of 1.5 for the SNP, assuming $\alpha=0.05$ and the two tailed test.

Peripheral blood samples $(5 \mathrm{ml})$ were collected from the 112 HTLV-1 positive individuals. Infected individuals were identified by the HTLV enzyme immunoassays Murex HTLV I + II (Abbott/Murex, Wiesbaden, Germany) and Vironostika HTLVI/II (bioMérieux bv, Boxtel, Netherlands), and infection was confirmed by HTLV BLOT 2.4 (HTLV blot 2.4, Genelabs Diagnostics, Science Park,. Singapore). Of these, 81 (72.3\%) were asymptomatic carriers (ACs), 24 (21.4\%) had HAM/TSP and $7(6.3 \%)$ had ATLL. All ACs were diagnosed as HTLV-1 carriers at the time of blood donation. The clinical status of HAM/TSP was determined based on WHO criteria for HTLV-1 associated diseases [29]. Diagnostic criteria for ATLL included serologic evidence of HTLV-1 infection and cytologically or histologically proven $\mathrm{T}$ cell malignancy. Written informed consent was obtained from each participant. The study was approved by the local review board (Comissão de Ética para Análise de Projetos de Pesquisa, CAPPesq).

Laboratory measurements included peripheral blood lymphocyte counts, quantitative measurement of HTLV-1 PvLs with the use of sensitive SYBR Green Real-Time PCR with a detection limit of 1 copy per $10^{3}$ PBMC cells, and HTLV-1 genotypes [30]. The results were obtained from the patients' medical records.

Based on the published human chromosome 19q13 sequence (NCBI Reference Sequence: NT_011109.16), a 293 base pair segment upstream of the IL-28 gene, flanking the rs12979860 polymorphism between nucleotides 12006835 and 120071103, relative to the chromosome 19 translational start codon, was analyzed. This region was PCR-amplified from genomic DNA using the forward primer 5'-GCTCAGCGCCTCTTCCTCCTGCG-3' and the reverse primer 5'-GGCAGGGCTCCCTTCTGTGATT GACC-3'. The PCR conditions consisted of an initial denaturation step at $95^{\circ} \mathrm{C}$ for 3 minutes, followed by 35 cycles of $95^{\circ} \mathrm{C}$ for 30 seconds, $58^{\circ} \mathrm{C}$ for 30 seconds and $68^{\circ} \mathrm{C}$ for 1 minute, and a final extension at $68^{\circ} \mathrm{C}$ for $5 \mathrm{~min}$ utes. Negative controls without the DNA template were included in each experiment. After termination of the PCR cycle, the products were purified using a QIA quick PCR purification kit (Qiagen). Complementary DNA strands from each amplicon were directly sequenced by cycle sequencing using the same primers used for the PCR, BigDye terminator chemistry and Taq polymerase on an automated sequencer (ABI 3130, Applied Biosystems Inc., Foster City, CA), according to the protocols recommended by the manufacturer.

Continuous variables, including PvLs, were presented as the median (range) or mean \pm standard deviation, while allelic frequencies were estimated by direct allele counting and were expressed as frequencies (\%). Deviation from 
Hardy-Weinberg equilibrium was tested by a standard $\chi^{2}$ test with 1 degree of freedom. Differences between PvL variables were assessed by means of Student's $t$ test with the non-parametric U-Mann-Whitney test, while those between allelic frequencies variables were evaluated using the Pearson $\chi^{2}$ test with Yate's correction or Fisher's exact test, when appropriate. A $p$ value $<0.05$ was considered significant. The data were analyzed with Stata statistical software (StataCorp, release 5.0, 1997; Stata, College Station, TX).

\section{Results}

In total, 112 blood samples from HTLV-1 infected individuals were included in the study. The participants' ages ranged between 24 and 73 years, and the median age was 55 years. Females constituted $62.5 \%(n=70)$ of the study population. The median measurements of $\mathrm{CD} 4$, CD8 and CD25 lymphocyte percentage by flow cytometry (FACScan, Becton-Dickinson, Cowley, Oxford) were $45 \%, 26 \%$, and $22 \%$, respectively, in $65 \%$ of subjects. The main characteristics of the study population are given in Table 1.

The median PvL and the frequency of clinical status among subjects are shown in Figure 1A. The PvL levels were significantly higher in both HAM/TSP patients (median 60 copies/1000 PBMCs) and ATLL patients (median 272 copies/1000 PBMCs) $(p<0.0001$, for each), compared to ACs.

In the entire group, the frequencies of the $\mathrm{CC}, \mathrm{CT}$ and TT genotypes of rs 12979860 were $45 \%, 48 \%$ and $7 \%$, respectively, reflecting a $\mathrm{C}$ allele frequency of $93 \%$. The calculated distribution of the rs12979860 alleles according to the Hardy-Weinberg equilibrium was $69 \%$ for the $\mathrm{C}$ allele and $31 \%$ for the $\mathrm{T}$ allele. Because of the small

Table 1 Characteristics of the 112 study subjects

\begin{tabular}{ll}
\hline Age. Years & \\
\hline Mean \pm SD & $51.9 \pm 12.6$ \\
\hline Median & 55 \\
\hline Range & $24-73$ \\
\hline Gender (\%) & $42(37.5)$ \\
\hline Male & $70(72.5)$ \\
\hline Female & \\
\hline Median lymphocyte subpopulations & 45 \\
\hline$\%$ CD4 cells & 26 \\
\hline$\%$ CD8 cells & 22 \\
\hline$\%$ CD25 cells & $81(72.3)$ \\
\hline Clinical status (\%) & $24(21.4)$ \\
\hline Asymptomatic carriers & $7(6.3)$ \\
\hline HAM/TSP &
\end{tabular}

number of subjects who were homozygous for the TT allele $(n=7)$, and because PvL values in individuals with this genotype and in individuals that have the heterozygote CT genotype were not significantly different $(p=0.4)$, subjects that were homo- or heterozygotes for the $\mathrm{T}$ mutated allele (CT/TT) were grouped together for further analysis. Next, we analyzed the relationship between the PvL levels and the rs12979860 alleles. As shown in Figure 1B, the median HTLV-1 PvL levels did not differ significantly between subjects carrying the rs $12979860 \mathrm{CC}$ genotype (median 57.5 copies/1000 PBMCs) and patients with a CT genotype (median 48 copies/1000 PBMCs) or a TT genotype (median 53.5 copies/1000 PBMCs) $(p=0.7)$.

We further aimed to analyze the data for potential correlates of clinical status and frequencies of the rs12979860 SNP. To this end, a comparison was made between patients with HAM/TSP and HTLV-1 ACs. Because of the small number of subjects $(n=7 ; 2$ CC, $5 \mathrm{CT}$ and $1 \mathrm{TT}$ ), ATLL patients were excluded from analysis. The frequency of the rs12979860 CC genotype was $43.2 \%$ among the $81 \mathrm{AC}$ subjects and $54.2 \%$ among the 24 patients with HAM/TSP $(p>0.5)$. Similarly, the frequency of the CT/TT genotypes was not appreciably different between the two groups ( $p>0.5$; Figure 2).

The transcontinental subgroup A of HTLV-1a was the major subtype accounting for $90.4 \%$ of the studied subjects. No significant difference in the frequencies of the rs12979860 genotypes identified was found in this study, when HTLV-1 subtypes were compared.

\section{Discussion}

In this study, we sought to replicate specific findings of association between the polymorphism rs12979860 in the vicinity of the IL28 gene and the HTLV-1 PvL, which is itself a predictive factor for development of HAM/ TSP or ATLL [14,32-36]. However, our data reveal no support for association between this SNP and HTLV-1 proviral DNA levels, in Brazilian subjects, regardless of whether they are symptomatic or are ACs. The results also held true when the analysis was extended to compare the rs12979860 polymorphism frequencies in patients that have HAM/TSP, have ATLL or are asymptomatic carriers. Recently, Treviño et al. [28] have reported a significantly greater frequency of the CT/TT allelic variant in patients with HAM/TSP than in ACs ( $80 \%$ vs. $20 \%$; $p=0.03$ ), and a significantly higher median HTLV-1 PvL was found in individuals with the CT/TT variant than in those with the CC variant $(p=0.01)$. In contrast to this report, our data do not support the IL28B gene polymorphism as a novel genetic susceptibility marker, either for HTLV-1-associated HAM/TSP nor ATLL, despite involving more than twice as many cases of HAM/TSP as the recent study [28]. The reasons for this discrepancy remain unclear, but it is possible that the original asso- 

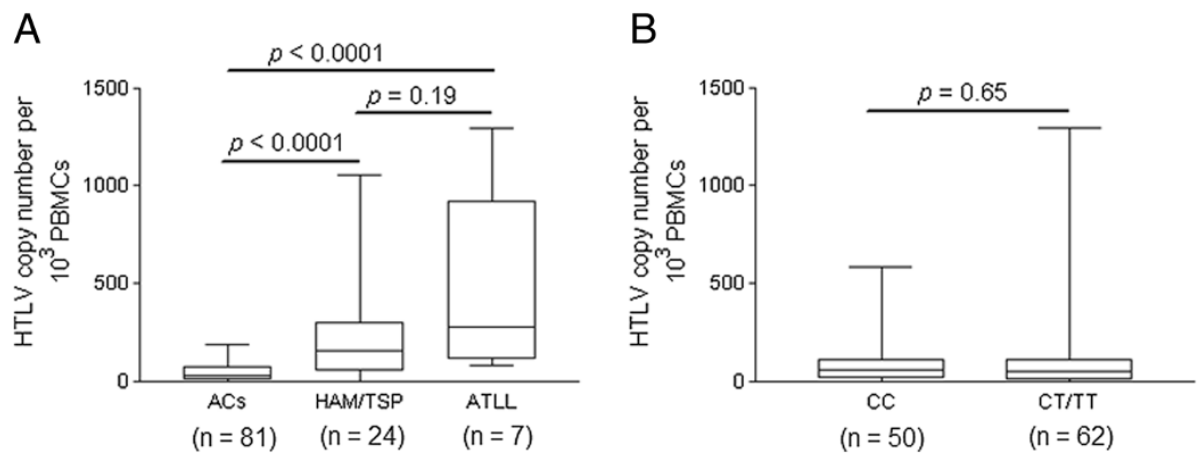

Figure 1 Distribution of HTLV-1 proviral load levels among study subjects. (A) Box and Whiskers plot of HTLV-1 proviral load in asymptomatic HTLV-1 carriers, HTLV-1-associated myelopathy/tropical spastic paraparesis patients and Adult T Cell Leukemia/Lymphoma. (B) Interleukin 28B CC versus CT/TT allelic variants.

ciations for these SNP were either due to chance or were overestimated due to the small sample size. It seems highly unlikely that this inconsistency in findings may stem from different methods used to assign the rs12979860 polymorphisms. The initial study used an allelic discrimination fluorogenic probe, and we used direct sequencing approach, which is still considered to be the gold standard. We believe that these 2 methods are similar to each other, and we assume that there is no difference in the definition of the term "genotype" between the two studies. We acknowledge that our data must be interpreted cautiously, and we cannot rule out sampling bias that results from the small sample size of this study. However, we believe that if the findings of the recent study were not due to chance, they might generalize beyond the HTLV-1 infected subjects reported in that study. Unfortunately, our study provides no support for that hypothesis and argues that the association of the IL28B polymorphism and the risk of HAM/TSP be viewed with skepticism; many of the statistical associations between a disease and alleles of specific genes have been irreproducible in the past [37].

Several recent studies have also assessed the association of the IL28B rs12979860 SNP in other viral infections in

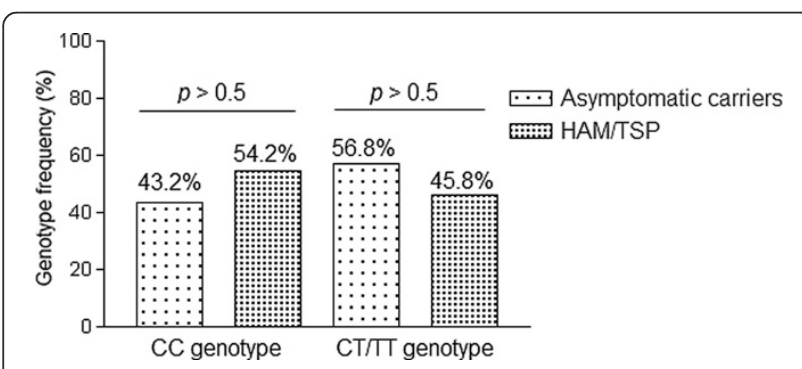

Figure 2 Comparison of the frequencies of interleukin (IL) $28 \mathrm{~B}$ rs 12979860 CC and CT/TT allelic variants between asymptomatic HTLV-1 carriers and HTLV-1-associated myelopathy/tropical spastic paraparesis patients. which IFN plays a critical role, and the results of those studies were similar to ours. For instance, the study by Rallon et al. [38] found a nonsignificant association between IL28B polymorphisms and neither HIV disease progression nor HIV protection in a sample of 29 seronegative individuals at risk for HIV-infection and in 68 HIV-positive carriers either with or without rapid progression of immunodeficiency. Martin et al. [39] also found a nonsignificant association between IL28B SNP and recovery of hepatitis B virus (HBV) infection in a sample of 226 individuals with HBV persistence and 384 with HBV recovery. Furthermore, Scagnolari and colleagues [31] reported a lack of association between IL28B SNP and the clinical course of bronchiolitis caused by respiratory syncytial virus. Yet another recent study by Kamihira et al. [40] reported that the frequency of the rs8099917, located $3 \mathrm{~kb}$ upstream the IL28B/IFN-13 gene [21], had no significant association with susceptibility to HTLV-1 infection or the development of ATLL in the Japanese subjects. Therefore, it is unlikely that the two SNPs (rs8099917 and rs12979860) are predictive factor for development of HAM/TSP or ATLL. Future studies are required to determine the extent to which differences in the ILB28 rs12980275 allelic variants frequencies between HTLV-1 infected subjects predict disease prevalence differences between populations.

\section{Conclusions}

We observed no compelling evidence of an association between the IL28B allelic variants and HTLV-1 PvL. Additionally, we were unable to confirm the hypothesis that the IL28B CT/TT polymorphisms might be a genetic marker for HTLV-1-associated HAM/TSP risk. These findings do not support the clinical utility of either testing for the IL28B in all asymptomatic HTLV-1 individuals, or closer follow-up of IL28B CT/TT carriers, as these steps could put us at risk of diverting financial resources from research areas that might make more of a 
difference in our understanding of the etiological mechanisms of HTLV-1 associated disease.

\section{Competing interests}

The authors declare that they have no competing interests.

\section{Authors' contributions}

SSS wrote the manuscript and directed the study. YN, JP, FEL, ACS and EGK were responsible of the clinical management of patients and acquisition of data, ACC, ACSO RP participated in the design of study, performed the experiments and the statistical analysis. FEL, EGK and ECS contributed to drafting the manuscript. All authors read and approved the final version of the manuscript.

\section{Acknowledgements}

This work was supported by grant 2010/08550-1 and 2011/12297-2 from the São Paulo Research Foundation (FAPESP).

\section{Author details}

${ }^{1}$ Clinical Laboratory, Department of Pathology, LIM 03, Hospital das Clínicas (HC), School of Medicine, University of São Paulo, São Paulo, Brazil. ${ }^{2}$ São Paulo Inistitute of Tropical Medicine, São Paulo, Brazil. ${ }^{3}$ Department of Hematology, University of São Paulo, São Paulo, Brazil. ${ }^{4}$ Division of Clinical Immunology and Allergy, University of Sao Paulo Medical School, São Paulo, Brazil. ${ }^{5}$ Deparment of Infectious Diseases, School of Medicine, University of Sao Paulo, São Paulo, Brazil.

Received: 10 July 2012 Accepted: 20 December 2012

Published: 23 December 2012

\section{References}

1. Poiesz BJ, Ruscetti FW, Gazdar AF, Bunn PA, Minna JD, Gallo RC: Detection and isolation of type $C$ retrovirus particles from fresh and cultured lymphocytes of a patient with cutaneous T-cell lymphoma. Proc Natl Acad Sci U S A 1980, 77(12):7415-7419.

2. Edlich RF, Arnette JA, Williams FM: Global epidemic of human T-cell lymphotropic virus type-I (HTLV-I). J Emerg Med 2000, 18(1):109-119.

3. Matsuoka M: Human T-cell leukemia virus type I and adult T-cell leukemia. Oncogene 2003, 22(33):5131-5140.

4. Verdonck K, Gonzalez E, Van Dooren S, Vandamme AM, Vanham G, Gotuzzo E: Human T-lymphotropic virus 1: recent knowledge about an ancient infection. Lancet Infect Dis 2007, 7(4):266-281.

5. Franchini G, Ambinder RF, Barry M: Viral Disease in Hematology. Hematology (Am Soc Hematol Educ Program) 2000:409-423.

6. Murphy EL, Hanchard B, Figueroa JP, Gibbs WN, Lofters WS, Campbell M, Goedert JJ, Blattner WA: Modelling the risk of adult T-cell leukemia/ lymphoma in persons infected with human T-lymphotropic virus type I. Int J Cancer 1989, 43(2):250-253.

7. Yamaguchi $\mathrm{K}$, Watanabe T: Human T lymphotropic virus type-I and adult T-cell leukemia in Japan. Int J Hematol 2002, 76(Suppl 2):240-245.

8. Matsuoka M, Jeang KT: Human T-cell leukaemia virus type 1 (HTLV-1) infectivity and cellular transformation. Nat Rev Cancer 2007, 7(4):270-280

9. Yoshida M, Seiki M, Yamaguchi K, Takatsuki K: Monoclonal integration of human T-cell leukemia provirus in all primary tumors of adult T-cell leukemia suggests causative role of human T-cell leukemia virus in the disease. Proc Natl Acad Sci U S A 1984, 81(8):2534-2537.

10. Takeda S, Maeda M, Morikawa S, Taniguchi Y, Yasunaga J, Nosaka K, Tanaka Y, Matsuoka M: Genetic and epigenetic inactivation of tax gene in adult T-cell leukemia cells. Int J Cancer 2004, 109(4):559-567.

11. Mesnard JM, Barbeau B, Devaux C: HBZ, a new important player in the mystery of adult T-cell leukemia. Blood 2006, 108(13):3979-3982.

12. Koziel MJ: Cytokines in viral hepatitis. Semin Liver Dis 1999, 19(2):157-169.

13. Tsukasaki K, Miller CW, Kubota T, Takeuchi S, Fujimoto T, Ikeda S, Tomonaga M, Koeffler HP: Tumor necrosis factor alpha polymorphism associated with increased susceptibility to development of adult T-cell leukemia/ lymphoma in human T-lymphotropic virus type 1 carriers. Cancer Res 2001, 61(9):3770-3774.

14. Jeffery KJ, Usuku K, Hall SE, Matsumoto W, Taylor GP, Procter J, Bunce M, Ogg GS, Welsh KI, Weber JN, et al: HLA alleles determine human T-lymphotropic virus-I (HTLV-I) proviral load and the risk of HTLV-I-associated myelopathy. Proc Natl Acad Sci U S A 1999, 96(7):3848-3853.
15. Jeffery $K J$, Siddiqui AA, Bunce M, Lloyd AL, Vine AM, Witkover AD, Izumo S, Usuku K, Welsh Kl, Osame M, et al: The influence of HLA class I alleles and heterozygosity on the outcome of human T cell lymphotropic virus type I infection. J Immunol 2000, 165(12):7278-7284.

16. Nishimura Y, Okubo R, Minato S, Itoyama Y, Goto I, Mori M, Hirayama K, Sasazuki T: A possible association between HLA and HTLV-I-associated myelopathy (HAM) in Japanese. Tissue Antigens 1991, 37(5):230-231.

17. Nishimura M, Maeda M, Matsuoka M, Mine H, Saji H, Matsui M, Kuroda $Y$, Kawakami H, Uchiyama T: Tumor necrosis factor, tumor necrosis factor receptors type 1 and 2, lymphotoxin-alpha, and HLA-DRB1 gene polymorphisms in human T-cell lymphotropic virus type I associated myelopathy. Hum Immunol 2000, 61(12):1262-1269.

18. Nishimura M, Matsuoka M, Maeda M, Mizuta I, Mita S, Uchino M, Matsui M, Kuroda Y, Kawakami H, Kaji R, et al: Association between interleukin-6 gene polymorphism and human T-cell leukemia virus type I associated myelopathy. Hum Immunol 2002, 63(8):696-700.

19. Sabouri AH, Saito M, Lloyd AL, Vine AM, Witkover AW, Furukawa Y, Izumo S, Arimura K, Marshall SE, Usuku K, et al: Polymorphism in the interleukin-10 promoter affects both provirus load and the risk of human $\mathrm{T}$ lymphotropic virus type l-associated myelopathy/tropical spastic paraparesis. J Infect Dis 2004, 190(7):1279-1285.

20. Gadelha SR, Junior Alcantara LC, Costa GC, Acosta AX, Rios D, Kashima S, Covas DT, Galvao-Castro B: Correlation between polymorphisms at interleukin- 6 but not at interleukin-10 promoter and the risk of human T lymphotropic virus type l-associated myelopathy/tropical spastic paraparesis in Brazilian individuals. J Med Virol 2008, 80(12):2141-2146.

21. Ge D, Fellay J, Thompson AJ, Simon JS, Shianna KV, Urban TJ, Heinzen EL, Qiu P, Bertelsen AH, Muir AJ, et al: Genetic variation in IL28B predicts hepatitis C treatment-induced viral clearance. Nature 2009, 461(7262):399-401.

22. Suppiah $\mathrm{V}$, Moldovan M, Ahlenstiel G, Berg T, Weltman M, Abate ML, Bassendine M, Spengler U, Dore GJ, Powell E, et al: IL28B is associated with response to chronic hepatitis $C$ interferon-alpha and ribavirin therapy. Nat Genet 2009, 41(10):1100-1104.

23. Tanaka Y, Nishida N, Sugiyama M, Kurosaki M, Matsuura K, Sakamoto N, Nakagawa M, Korenaga M, Hino K, Hige S, et al: Genome-wide association of IL28B with response to pegylated interferon-alpha and ribavirin therapy for chronic hepatitis C. Nat Genet 2009, 41(10):1105-1109.

24. Thompson AJ, Muir AJ, Sulkowski MS, Ge D, Fellay J, Shianna KV, Urban T, Afdhal NH, Jacobson IM, Esteban R, et al: Interleukin-28B polymorphism improves viral kinetics and is the strongest pretreatment predictor of sustained virologic response in genotype 1 hepatitis $\mathrm{C}$ virus. Gastroenterology 2010, 139(1):120-129. e118.

25. Rauch A, Kutalik Z, Descombes P, Cai T, Di lulio J, Mueller T, Bochud M, Battegay M, Bernasconi E, Borovicka J, et al: Genetic variation in IL28B is associated with chronic hepatitis $C$ and treatment failure: a genome-wide association study. Gastroenterology 2010, 138(4):1338-1345. 1345 e1331-1337.

26. Rallon NI, Naggie S, Benito JM, Medrano J, Restrepo C, Goldstein D, Shianna $\mathrm{KV}$, Vispo E, Thompson A, McHutchison J, et al: Association of a single nucleotide polymorphism near the interleukin-28B gene with response to hepatitis $\mathrm{C}$ therapy in HIV/hepatitis C virus-coinfected patients. AIDS 2010, 24(8):F23-F29.

27. Nattermann J, Vogel M, Nischalke HD, Danta M, Mauss S, Stellbrink HJ, Baumgarten A, Mayr C, Bruno R, Tural C, et al: Genetic variation in IL28B and treatment-induced clearance of hepatitis $C$ virus in HIV-positive patients with acute and chronic hepatitis C. J Infect Dis 2011, 203(5):595-601.

28. Trevino A, Lopez M, Vispo E, Aguilera A, Ramos JM, Benito R, Roc L, Eiros JM, de Mendoza C, Soriano V: Development of Tropical Spastic Paraparesis in Human T-Lymphotropic Virus Type 1 Carriers Is Influenced by Interleukin 28B Gene Polymorphisms. Clin Infect Dis 2012, 55(1):e1-e4.

29. Osame: Review of WHO Kagoshima Meeting and diagnostic guidelines for HAM/TSP. In Human Retrovirology: HTLV. Edited by Blattner W. New York: Raven; 1990:191-197.

30. Neto WK, Da-Costa AC, de Oliveira AC, Martinez VP, Nukui Y, Sabino EC, Sanabani SS: Correlation between LTR point mutations and proviral load levels among human T cell lymphotropic virus type 1 (HTLV-1) asymptomatic carriers. Virol J 2011, 8:535.

31. Scagnolari C, Midulla F, Riva E, Monteleone K, Solimini A, Bonci E, Cangiano G, Papoff P, Moretti C, Pierangeli A, et al: Evaluation of interleukin 28B 
single nucleotide polymorphisms in infants suffering from bronchiolitis. Virus Res 2012, 165(2):236-240.

32. Nagai M, Usuku K, Matsumoto W, Kodama D, Takenouchi N, Moritoyo T, Hashiguchi S, Ichinose M, Bangham CR, Izumo S, et al: Analysis of HTLV-I proviral load in 202 HAM/TSP patients and 243 asymptomatic HTLV-I carriers: high proviral load strongly predisposes to HAM/TSP. J Neurovirol 1998, 4(6):586-593.

33. Iwanaga M, Watanabe T, Utsunomiya A, Okayama A, Uchimaru K, Koh KR Ogata M, Kikuchi H, Sagara Y, Uozumi K, et al: Human T-cell leukemia virus type I (HTLV-1) proviral load and disease progression in asymptomatic HTLV-1 carriers: a nationwide prospective study in Japan. Blood 2010, 116(8):1211-1219.

34. Gabet AS, Mortreux F, Talarmin A, Plumelle Y, Leclerca I, Leroy A, Gessain A, Clity E, Joubert M, Wattel E: High circulating proviral load with oligoclonal expansion of HTLV-1 bearing T cells in HTLV-1 carriers with strongyloidiasis. Oncogene 2000, 19(43):4954-4960.

35. Kamihira S, Dateki N, Sugahara K, Hayashi T, Harasawa H, Minami S, Hirakata Y, Yamada Y: Significance of HTLV-1 proviral load quantification by realtime PCR as a surrogate marker for HTLV-1-infected cell count. Clin Lab Haematol 2003, 25(2):111-117.

36. Manns A, Miley WJ, Wilks RJ, Morgan OS, Hanchard B, Wharfe G, Cranston B, Maloney E, Welles SL, Blattner WA, et al: Quantitative proviral DNA and antibody levels in the natural history of HTLV-I infection. J Infect Dis 1999, 180(5):1487-1493.

37. Jonsson JR, Purdie DM, Clouston AD, Powell EE: Recognition of genetic factors influencing the progression of hepatitis $C$ : potential for personalized therapy. Mol Diagn Ther 2008, 12(4):209-218.

38. Rallon NI, Restrepo C, Naggie S, Lopez M, Del Romero J, Goldstein D, McHutchison J, Soriano V, Benito JM: Interleukin-28B gene polymorphisms do not influence the susceptibility to HIV-infection or CD4 cell decline. AIDS 2011, 25(2):269-271

39. Martin MP, Qi Y, Goedert JJ, Hussain SK, Kirk GD, Hoots WK, Buchbinder S, Carrington M, Thio CL: IL28B polymorphism does not determine outcomes of hepatitis B virus or HIV infection. J Infect Dis 2010, 202(11):1749-1753.

40. Kamihira S, Usui T, Ichikawa T, Uno N, Morinaga Y, Mori S, Nagai K, Sasaki D, Hasegawa H, Yanagihara K, et al: Paradoxical expression of IL-28B mRNA in peripheral blood in human T-cell leukemia virus type-1 monoinfection and co-infection with hepatitis C virus. Virol J 2012, 9:40,

doi:10.1186/1471-2334-12-374

Cite this article as: Sanabani et al:: Lack of evidence to support the association of a single IL28B genotype SNP rs 12979860 with the HTLV-1 clinical outcomes and proviral load. BMC Infectious Diseases 2012 12:374.

\section{Submit your next manuscript to BioMed Central and take full advantage of:}

- Convenient online submission

- Thorough peer review

- No space constraints or color figure charges

- Immediate publication on acceptance

- Inclusion in PubMed, CAS, Scopus and Google Scholar

- Research which is freely available for redistribution 